\title{
ENVIRONMENTAL ISSUES IN THE CONTEXT OF HEALTH SUPPORT IN THE THINKING OF STUDENT TEACHERS
}

The author presents the results of research among future teachers of lower classes of elementary schools on environmental issues - specifically on the issue of an environmentally friendly lifestyle in the context of health support. Describing the thinking, opinions, attitudes, and values of student teachers can influence the curriculum content of preparatory and further education.

Key words: Environmental education, eco-pedagogical competence, relation to nature, students' attitudes and values, health, health education

The frequency of ecological/environmental themes (dealing with bio-diversity, the ozone hole, the green-house effect, acid rain, climate change, and other problems, in addition to ways to solve them) in school curricula is undoubtedly getting higher. Given the important role of the teacher in environmental education and the high requirements for abilities to realize ecological/environmental education, i.e. for high eco-pedagogical competence, we tried to describe how future teachers think about environmental themes (see Horká; Bubeliniová, 2004).

\section{Introduction}

The goal of the research is to report the views and thoughts, the attitudes and values of the respondents concerning relations and behaviour towards nature (the environment) in the context of health support.

We exploratively used the method of content analysis of works (essays), written by forty-six second-year students of a combined study program for teaching in the lower classes of elementary schools in the 2004/2005 school year. The theme was: Values and the environment in the context of my life. We consider the results only to be relevant for this group of students.

In the investigated theme, the following categories became fundamental for the students: the protection of nature, childhood and education, the future - consideration for future generations, the use of nature (both positive and negative), values and attitudes in connection to environmental problems, and health.

\section{Results and Interpretations}

Our interpretations of individual analytic categories are supplemented by authentic statements from respondents in order to form a more complex picture of their thinking. Given the sample of respondents (46 students), we interpret the results as relevant for this group only.
The protection of nature category includes activities that the participants consider to be beneficial to nature (the environment). In their essays, 34 out of 46 students consider the sorting of waste materials as important (they either sort and recycle waste themselves or emphasise its importance). From a research point of view it is interesting that a common feature in most participants' view of ecological behaviour is the area of the recycling and sorting of waste. Nevertheless there is a wide range of other activities beneficial to the environment. Another important characteristic of the given set ( 24 students out of 46 ) is their mention of the issue of conservation of water and energy.

Examples: "Now, after a long delay, I am starting with more intensive energy saving in housework, I pay more attention to waste material sorting..." "I do not spend half an hour showering, I do not clean my teeth with running water, I partially sort waste, I walk, ride a bike but also drive a car, quite often I lean to pick up a piece of paper from the pavement, I do not destroy the environment."

"... the proper use of pot lids; the TV is on only when it is being watched; just after reaching the boiling-point, I decrease the temperature; while baking chicken must be covered because it takes less time; we use a PC a lot and we do not spoil it by repeatedly switching it on and off; running the washing machine and dish washer only when they are full; economical ventilation; heating regulators; rain water for watering plants; economical dish washers; alternative water levels in toilets; water batteries that do not leak.

"I teach my daughter not to waste food and water; we try to save electricity and heat. I try to make her feel that sorting waste is a task for everybody, that it is a personal choice. I sort because I consider it right, because I want to do it. Not because it is on TV, but because it is right."

Out of the 46 students, 18 write in their essay about the direct protection of nature in the area of caring for forests, vegetation, landscapes (planting trees, cleaning forests, etc.), e.g.:

"We started cleaning the forest; we created a small lake there, various paths."

\footnotetext{
* Hana Horká

Faculty of Pedagogy, Masaryk University, Brno, Czech Republic, E-mail: horka@ped.muni.cz
} 
“...children look after the order in woods." "I helped with planting trees..."

"I do not use any poisons or other sprays for killing weeds. I do not use any sprays even on paprika although it is often attacked by plant lice. I am breeding a frog in a green house; in spring I will bring the young frog to a small pool in the greenhouse and it will kill the insects. When autumn comes the little frog will jump away to a nearby stream..."

About a third of respondents mention problems resulting from using cars: e.g.: "I prefer walking, riding a bike or taking public transportation to driving a car"; "going on foot more and doing nothing that would cause me in any way to consciously harm the environment"; "I use public transportation and a bicycle"; "it is not possible to live without transportation these days, which is why we have a car with a catalyser of exhaust fumes".

\section{Childhood and Education Category}

24 out of 46 students say that experience at a young age with the natural environment significantly influences life attitudes (compare with Franěk, 2000). They appreciate education directed towards the love and protection of nature in their own or entrusted children. 22 respondents recall their first experience connected with emotional enjoyments from their childhood, e.g.:

"I was taught from a young age about the protection of the environment around us. My parents were good example in that respect.

In the lower classes of elementary school, I attended a "protector of nature" circle and in higher classes in a course of Labour education we looked after the Eco-area of our school."

"My parents always taught me to like nature, to think highly of it and to feel joy from every plant and every animal."

"If you do not get some knowledge from adults at a young age, you cannot come to the realization that you should start an investigation on your own"

"A small child starts to detect, in its early steps starts to admire the magic of nature."

"I teach my daughter not to waste food and water; we try to save electricity and heat."

"But children learn quickly, much faster than adults. They are full of energy; they are enthusiastic to manage great things."

"Even my almost three-year-son takes sorting of home waste as a matter of course."

\section{The Future - Consideration for Future Generations Category}

21 out of 46 students mention fears about the future of their own children (or of the next generations) and try to suggest the ways to solve them, e.g.:

"Not until recently have we realised that until now we have been cutting off our own children from a clean environment due to our selfish way of life."
"In a short time we will become "greenhouse people" who will not be resistant to any bacteria and will be permanently ill."

"If the attitude of all people to nature is the same as I see it in my surroundings, then the future of our children will not be good."

"I am glad that I have come to the opinion that there is a need to start acting in order to ensure an ecologically clean planet for future generations. Or is it already late?"

"Only now, through these marvellous times spent in nature, have I started meditating over the importance for me of the feeling that my son will be able, after several years, to experience the same moments of happiness with his children."

And how should the situation be solved? The students propose, e.g.

"Think globally, act locally; make changes individually."

"I might live in a less consuming way and think more about the future of my children."

"Towards my son I have a bad conscience now and these values are becoming important for me only now..."

"In 1980 the Bílé Karpaty mountain range was proclaimed a protected landscape region.

That is the reason why the region should be preserved for future generations. We have to teach ourselves and also the younger generation what we all have already forgotten. It is to treasure nature and to live in compliance with it."

"The worst thing is that the situation is not going to change, because what kind of politician would put into his programme a decrease of industrial economy in order to improve the state of nature?"

\section{Positive Uses of Nature Category}

18 out of 46 students judge the importance of nature from their personal point of view, particularly its recreational, aesthetic and cognitive values, e.g.:

"In nature we all are equal; there are no foreigners, no natives; in nature we are at home everywhere." "We often go to the countryside, to weekend houses, to rivers and lakes, to the mountains."

"We often go to the woods and we like it."

"I love going to the mountains for hiking."

"...trips to the countryside"

"...hiking, sleeping outdoors, camping..."

"...to learn the woods in any weather"

"Could there be anything more pleasant than what nature itself presents to us: when we occasionally stop somewhere and notice a beautiful sunset; a clean, babbling brook; how calm and quiet the evening is?"

"I love hiking and cycling in nature."

\section{Health Category}

We investigated the context of an ecologically friendly lifestyle and health support. We found that 16 out of 46 students explicitly mention the item of health in their essays. 
Examples: "Our health and that of our nearest relatives is the most precious value we have in our lives. And even the words "environment" and "lifestyle" are closely connected with it."

"I believe that if somebody really strives to live in a healthy way and also holds all the principles of environmental protection, then such a life becomes, in fact, his lifestyle."

"If everybody did just the minimum for the environment, then plastic bags and papers would not have to float in the air instead of kites and there might be fewer people with allergies."

The students perceive the environment as a risk factor for their quality of life, especially for their health. A lifestyle unfavourable towards the environment becomes a menace. A consumer lifestyle has a risky influence on the environment. The students identify a "healthy life style" with "ecological behaviour".

Examples: "Most adults list health, love, and happiness among their primary values..."

"A healthy life style includes healthy nourishment and food. I cannot say that I only eat low-calorie food, but I strive to eat regularly, not to overeat, and to include fruits, vegetables, milk products, and fish into my dietary regimen."

"I like participating in sports."

"I like hiking and cycling in nature."

"I do not smoke."

"I would be lying if I declared that I never drive a car, never buy things that I might not use, that I do take part in demonstrations for healthy environment as a Greenpeace member on squares or near power stations."

"Ecological farms are an excellent idea. The animals would live in a limited area in a natural and dignified way. No doubt, it is more expensive, but on the other hand it is good. Consumption would drop and thus also mortality caused by obesity. Meat is very fattening and difficult to digest mainly in cases when the animal is standing in one place all day."

Education for health (for a healthy life style) becomes an effective strategy for improving the environment.

\section{Environmental Problems Versus Pro-Ecological Values and Attitudes}

The present state of the environment is perceived as a problematic one, as a source of health risks. The responsibility for the harm and damages lies on humans and their prevailing life style: preferring the needs of humans, the inability to give up lifelong habits, and the lack of respect for values that can neither be bought nor sold.

The indifference and indolence of people towards the environment is considered to be the biggest cause of the existing problems. Equally as significant is the conformity in rejecting the extreme, narrow-minded anthropocentric attitude towards the environment. This can be considered as a positive signal for the future.

Examples: "There is less and less unspoilt nature, it is disappearing from our surroundings. It runs to far-away places, into the mountains, but even there we chase it with roads, cable lifts and mountain hotels. Due to our longing for nature, we cut it into small, private portions and insert our civilized comforts into it."

"Pedestrian zones retreat, benches disappear, and in their place cars of those who "cannot" take a few steps fill up our squares."

"We need comfort."

"Otherwise, we want just to flip switches and push buttons..."

"Nature is free of charge and that might be the reason why we treat it as a cheap matter."

"It is easy to think about ecology when sitting at home and watching TV in short sleeves, when outside there is a biting frost. The meal we prepare there will leave a lot of waste and we will finish with a tasty drink from a plastic bottle."

"Industrial activities are mainly detrimental to the quality of the air, which is critical part of the life and health of people. Agricultural and building activities have a very negative influence on other elements of the environment around us."

From the responses we can deduce the steps in the formation of our respondents' lifestyles, and the influences of cultural habits on them. As a representative of the community, school has an important position in influencing the lifestyle of an individual. The respondents believe that good education is a pre-requisite for a sensitive and responsible attitude and behaviour towards nature. The basis for the declared qualitative change comes both from an awareness of duties coming from existence in nature and from the choice of an individual lifestyle favourable to the environment.

Examples: "Today I can see what I could not see before: birds singing from spring until autumn, green forests, forest animals, mountains, highlands, the colourfulness of nature and the countryside, beneficial sunlight. It is nice to be in the world and to sense all of it."

"Value systems are related to lifestyles, and lifestyles to the environment."

"I am an ordinary person who has never come across the issues actively, but I love nature and its devastation offends my aesthetic feelings."

"I say that we (people) are the most stupid creatures in the world. Our behaviour is incomprehensible and shocking. I can see it not only in my environment but also in myself."

"Sometimes I feel that we behave towards [nature] like absolute rulers of the world."

\section{Conclusion}

Through the identification of semantic units and analytic categories and the comparison of them with an expert discourse on environmental issues in the context of health support, we can discover possibilities for influencing the curricula of teacher training and education. Every university student should be able to assess the connection between the natural, social and humanitarian sciences and the importance of this connection for the well-being of humans. This verifies the need for a systematic formation of teachers' understanding of a healthy life style and general breadth of view and the ability of teachers to cultivate the personality and influence the value system of their pupils. 


\section{References:}

[1] FRANĚK, M.: Psychosocial factors influencing the success of Environmental education (in Czech), Český ekologický ústav, oddělení environmentálního vzdělávání, výchovy a osvěty, Praha, 2000, http://www.ceu.cz/edu/vyzkum/vyzkum.html

[2] De HAAN, G.: Umweltbewusstsein und Massenmedien Perspektiven ekologische Kommunikation, Akademie Verlag, Berlin, 1995 , p. 308.

[3] HORKÁ, H.: Environmental Dimensions of Upbringing and Education in the 21st Century School, (in Czech), PdF MU, Brno, 2005, ISBN 80-210-3750-4

[4] HORKÁ, H.; BUBELINIOVÁ, M.: Environmental topics discussed by the teachers and trainee-teachers (in Czech), Příprava učitelů pro primární vzdělávání v ČR a budoucí plánování scénářů v Evropě, Sborník Výzkumného záměru organizace VZO: msm 174500001, OU - Pedagogická fakulta, 2004, Ostrava, p. 223-240, ISBN 80-7042-376-5

[5] PALMER, J. A.: Environmental education in the $21^{\text {st }}$ Century, London- New York, 2003

[6] WIEGEROVÁ, A.: Health, health support and health education (in Slovak), OZ V4, Bratislava, 2004. ISBN 80-969146-4-2.

The paper is supported by the research intent of Ministry of Education, Youth and School (MSM0021622421) "Schooll and Health in 21. Century”. 